\title{
The role of mitochondria in longevity and healthspan
}

\author{
Martin D Brand
}

\begin{abstract}
The role of mitochondria in aging and disease remains contentious more than 40 years after the mitochondrial free radical theory of aging was first proposed. As part of a wider cross-journal series on contemporary mitochondrial biology, Longevity \& Healthspan presents a thematic series of four reviews that discuss the evidence for and against the modern incarnations of the theory, and examine the relevance of mitochondrial membrane phospholipid unsaturation and the interactions of mitochondria with sex hormones.
\end{abstract}

\section{Editorial}

Mitochondria are indispensable for aerobic life. Depending on the tissue and species, they normally occupy $2-20 \%$ of the volume of a cell, and it can be up to $50 \%$. They have their own DNA and undergo constant motion, fusion and fission. They provide the cell with ATP formed during the oxidation of carbohydrate, proteins and fats and are involved in a range of metabolic pathways including gluconeogenesis, urea synthesis, one-carbon metabolism, protein synthesis, amino acid metabolism, haem synthesis and hormone synthesis. They help regulate cellular calcium levels, trigger apoptosis, and can generate reactive oxygen species that are used in cellular signalling and can cause oxidative damage. Their many different roles are highlighted in a cross-journal thematic series including not only articles in Longevity $\mathcal{E}$ Healthspan, but also in Extreme Physiology \& Medicine, Cancer \& Metabolism and BMC Biology.

The hallmark of a useful hypothesis is that it stimulates further work and drives progress in its field. The free radical theory of aging has certainly done that since Harman proposed it in its general form in 1956 [1] and in a more mitochondrially-oriented form in 1972 [2]. This theory proposes that the primary cause of aging is mitochondrial production of free radicals and the mitochondrial damage that ensues. The evidence that has been gathered over the years has led to adjustments and refinements in the formulation of the hypothesis as

Correspondence: mbrand@buckinstitute.org

The Buck Institute for Research on Aging, 8001 Redwood Blvd, Novato, CA 94945, USA different authors have attempted to articulate it more precisely and to square it with experimental observations; as a result there have been numerous updates and overviews [3-6]. Many of these have been very influential - I remember first reading the seminal review by Beckman and Ames [7] and being impressed by the breadth of the circumstantial evidence that they highlighted. However, the perspective has become increasingly critical as the predicted beneficial effects of many antioxidant treatments and genetic manipulations have failed to materialise [8-14].

Where does that leave us today? On the one hand, many of the manipulations that should decrease aging and increase longevity according to the classical versions of the mitochondrial free radical theory of aging have failed to do so [15-18], implying that the theory is wrong, or at best deeply flawed. On the other hand, some of these manipulations have been very successful [19-22], implying that that the theory refracts some underlying reality and still has significant value as a guide to thought and experiment.

In this thematic series on the role of mitochondria in longevity and healthspan, Dai et al. [23] discuss the evidence relating to the free radical theory with an emphasis on results that are generally supportive. They review studies that support the role of mitochondrial oxidative stress and dysfunction in aging and healthspan, including cardiac aging, age-dependent cardiovascular diseases, skeletal muscle aging, neurodegenerative diseases, insulin resistance, diabetes and age-related cancers, then consider potential drugs to improve mitochondrial function in aging and healthspan. 
Stuart et al. [24] take the opposite tack, examining the evidence from long- and short-lived animal species, calorie restriction and genetically modified animals. They argue that the mitochondrial free radical theory of aging is in crisis because recent studies have shown no relationship between free radicals and longevity, and instead emphasize a role for mitochondrial reactive oxygen species as intracellular messengers. They propose that if mitochondrial reactive oxygen species are involved in aging and longevity, it is through specific and regulated cellular processes and not through indiscriminate oxidative damage.

An important mechanism that may link reactive oxygen species to cellular phenotypes is the oxidation of polyunsaturated fatty acyl groups in membrane phospholipids [25-27]. This topic is discussed by Valencak and Azzu [28], who review the many published correlations between mitochondrial membrane phospholipid composition and longevity. Although there are methodological issues, the ratio of $n-3: n-6$ polyunsaturated fatty acyl groups does appear to correlate with lifespan. However, they caution against simply relating these two traits because correlation is consistent with but does not prove a functional relationship.

One aspect of mitochondria and healthspan that has received less attention until recently is the role of sex steroid hormones. This is addressed by Velarde [29], who discusses the evidence that poorer healthspan is associated with declining circulating levels of these hormones [30-32]. Mitochondria are involved in steroid hormone synthesis, and in turn mitochondrial function may respond to sex hormones. He suggests that a decline in sex steroid hormones and accumulation of mitochondrial damage creates a positive feedback loop that may contribute to progressive degeneration in aging.

Together this set of four reviews illuminates several aspects of our contemporary understanding of the role of mitochondria in healthspan and longevity and should help to light the path ahead. Further unsolicited articles are encouraged to the series and should be submitted via the journal's online submission system.

Received: 6 May 2014 Accepted: 6 May 2014

Published: 22 May 2014

\section{References}

1. Harman D: Aging: a theory based on free radical and radiation chemistry. J Gerontol 1956, 11:298-300.

2. Harman D: The biologic clock: the mitochondria? J Am Geriatr Soc 1972, 20:145-147.

3. Harman D: Free-radical theory of aging. Increasing the functional life span. Ann N Y Acad Sci 1994, 717:1-15.

4. Yu BP, Yang R: Critical evaluation of the free radical theory of aging. A proposal for the oxidative stress hypothesis. Ann N Y Acad Sci 1996, 786:1-11

5. Cadenas E, Davies KJ: Mitochondrial free radical generation, oxidative stress, and aging. Free Radic Biol Med 2000, 29:222-230.

6. Harman D: Aging: overview. Ann N Y Acad Sci 2001, 928:1-21.
7. Beckman $\mathrm{KB}$, Ames $\mathrm{BN}$ : The free radical theory of aging matures. Physiol Rev 1998, 78:547-581.

8. Sanz A, Pamplona R, Barja G: Is the mitochondrial free radical theory of aging intact? Antioxid Redox Signal 2006, 8:582-599.

9. Muller FL, Lustgarten MS, Jang Y, Richardson A, Van Remmen H: Trends in oxidative aging theories. Free Radic Biol Med 2007, 43:477-503.

10. Gruber J, Schaffer S, Halliwell B: The mitochondrial free radical theory of ageing-where do we stand? Front Biosci 2008, 13:6554-6579.

11. Perez VI, Bokov A, Van Remmen H, Mele J, Ran Q, Ikeno Y, Richardson A: Is the oxidative stress theory of aging dead? Biochim Biophys Acta 2009, 1790:1005-1014

12. Bratic A, Larsson NG: The role of mitochondria in aging. J Clin Invest 2013, 123:951-957.

13. Barja G: Updating the mitochondrial free radical theory of aging: an integrated view, key aspects, and confounding concepts. Antioxid Redox Signal 2013, 19:1420-1445.

14. Pulliam DA, Bhattacharya A, Van Remmen H: Mitochondrial dysfunction in aging and longevity: a causal or protective role? Antioxid Redox Signal 2013, 19:1373-1387.

15. Huang TT, Carlson EJ, Gillespie AM, Shi Y, Epstein CJ: Ubiquitous overexpression of CuZn superoxide dismutase does not extend life span in mice. The journals of gerontology. J Gerontol A Biol Sci Med Sci 2000, 55:B5-9.

16. Bjelakovic G, Nikolova D, Gluud LL, Simonetti RG, Gluud C: Mortality in randomized trials of antioxidant supplements for primary and secondary prevention: systematic review and meta-analysis. JAMA 2007, 297:842-857.

17. Jang YC, Perez VI, Song W, Lustgarten MS, Salmon AB, Mele J, Qi W, Liu Y,

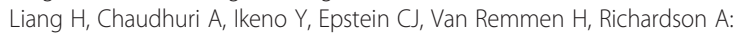
Overexpression of Mn superoxide dismutase does not increase life span in mice. The journals of gerontology. J Gerontol A Biol Sci Med Sci 2009, 64:1114-1125.

18. Perez VI, Van Remmen H, Bokov A, Epstein CJ, Vijg J, Richardson A: The overexpression of major antioxidant enzymes does not extend the lifespan of mice. Aging cell 2009, 8:73-75.

19. Schriner SE, Linford NJ, Martin GM, Treuting P, Ogburn CE, Emond M, Coskun PE, Ladiges W, Wolf N, Van Remmen H, Wallace DC, Rabinovitch PS: Extension of murine life span by overexpression of catalase targeted to mitochondria. Science 2005, 308:1909-1911.

20. Dai DF, Chen T, Wanagat J, Laflamme M, Marcinek DJ, Emond MJ, Ngo CP, Prolla TA, Rabinovitch PS: Age-dependent cardiomyopathy in mitochondrial mutator mice is attenuated by overexpression of catalase targeted to mitochondria. Aging cell 2010, 9:536-544.

21. Lee HY, Choi CS, Birkenfeld AL, Alves TC, Jornayvaz FR, Jurczak MJ, Zhang D, Woo DK, Shadel GS, Ladiges W, Rabinovitch PS, Santos JH, Petersen KF, Samuel VT, Shulman Gl: Targeted expression of catalase to mitochondria prevents age-associated reductions in mitochondrial function and insulin resistance. Cell metab 2010, 12:668-674.

22. Mao P, Manczak M, Calkins MJ, Truong Q, Reddy TP, Reddy AP, Shirendeb U, Lo HH, Rabinovitch PS, Reddy PH: Mitochondria-targeted catalase reduces abnormal APP processing, amyloid beta production and BACE1 in a mouse model of Alzheimer's disease: implications for neuroprotection and lifespan extension. Hum Mol Genet 2012, 21:2973-2990

23. Dai DF, Chiao YA, Marcinek D, Szeto H, Rabinovitch P: Mitochondrial oxidative stress in aging and healthspan. Longev Healthspan 2014, 3:6.

24. Stuart JA, Maddalena LA, Merilovich M, Robb EL: A midlife crisis for the mitochondrial free radical theory of aging. Longev Healthspan 2014, 3:4.

25. Pamplona R, Prat J, Cadenas S, Rojas C, Perez-Campo R, Lopez Torres M, Barja G: Low fatty acid unsaturation protects against lipid peroxidation in liver mitochondria from long-lived species: the pigeon and human case. Mech Ageing Dev 1996, 86:53-66.

26. Pamplona R, Portero-Otin M, Ruiz C, Gredilla R, Herrero A, Barja G: Double bond content of phospholipids and lipid peroxidation negatively correlate with maximum longevity in the heart of mammals. Mech Ageing Dev 2000, 112:169-183.

27. Hulbert AJ: On the importance of fatty acid composition of membranes for aging. J Theor Biol 2005, 234:277-288.

28. Valencak TG, Azzu V: Making heads or tails of mitochondrial membranes in longevity and aging: a role for comparative studies. Longev Healthspan 2014, 3:3.

29. Velarde MC: Mitochondrial and sex steroid hormone crosstalk during aging. Longev Healthspan 2014, 3:2 
30. Nieschlag E, Nieschlag S, Behre HM: Lifespan and testosterone. Nature. 1993, 366:215.

31. Henderson WW, Brinton RD: Menopause and mitochondria: windows into estrogen effects on Alzheimer's disease risk and therapy. Prog Brain Res 2010, 182:77-96.

32. O'Connell MD, Roberts SA, Srinivas-Shankar U, Tajar A, Connolly MJ, Adams $J E$, Oldham JA, WU FC: Do the effects of testosterone on muscle strength, physical function, body composition, and quality of life persist six months after treatment in intermediate-frail and frail elderly men? J Clin Endocrinol Metab 2011, 96:454-458.

doi:10.1186/2046-2395-3-7

Cite this article as: Brand: The role of mitochondria in longevity and healthspan. Longevity \& Healthspan 2014 3:7.

\section{Submit your next manuscript to BioMed Central and take full advantage of:}

- Convenient online submission

- Thorough peer review

- No space constraints or color figure charges

- Immediate publication on acceptance

- Inclusion in PubMed, CAS, Scopus and Google Scholar

- Research which is freely available for redistribution 